\title{
Comparison between Limbal Autograft Transplantation and Subconjunctival Bevacizumab Injection in Lowering Recurrence of Primary Pterygium
}

\author{
MOHAMMED A.E. MOUSTAFA, M.Sc.; MOHAMED Z. EID, M.D. and NOURELDIN A. ABDELHALIM, M.D. \\ The Department of Ophthalmology, Faculty of Medicine, Al-Azhar University
}

\begin{abstract}
Backogund: Pterygium is a common ocular surface disorder with a wing shaped fibrovascular overgrowth of bulbar conjunctiva onto the cornea and it is often triangular in shape and consists of a head, i.e., the part which rests on the cornea, a neck, and a body. It is a common conjunctival degenerative condition, which is characterized by elastotic degeneration of collagen and fibrovascular proliferation. Pterygium occurs as a result of breakdown of the corneoscleral limbal barrier results in subsequent conjunctivalization of the cornea, as the scattered light might follow alternative optical paths when entering the eye, thus hitting limbal stem cells from their inner surface.
\end{abstract}

Aim of Study: The aim of the current study was to compare the recurrence rate of limbal auto graft transplantation versus single intraoperative subconjunctival Bevacizumab injection after surgical removal of the primary Pterygium.

Patients and Methods: This was a prospective cohort study, the study was conducted on 20 eyes (10 Patients) with primary pterygium patients, attended the outpatient clinic of the Ophthalmology Department at Al-Azhar University Hospital (Cairo), during period from January 2021 to July 2021 Patients were being divided into equal 2 groups: Group 1: Pterygium was excised then limbalautograft was placed (10 eyes), and Group 2: Pterygium was excised followed by subconjunctival injection of bevacizumab (10 eyes).

Results: Hundered percent inlimbal group were not recurrent, and twenty percent of the conjunctival injection group was recurrent, and there was non-statistical significant difference between two groups as regard recurrence. Ninty percent in group A were +ve as regard improvement in visual acuity, and eighty percente of the participants in the group B had +ve improvement in visual acuity, and there was non-statistical significant difference between two groups as regard visual acuity improvement. Seventy percent of cases in group A had no congestion while all cases in group B had no congestion, and there was no statistical significant difference between two groups as regard congestion, while as regard ischemia, we found that all cases in group A had no ischemia while fourty percente in group B develop postoperative ischemia,

Correspondence to: Dr. Mohammed A.E. Moustafa, E-Mail: ophth.m.adel@ gmail.com and there was no statistical significant difference between two groups as regard ischemia. Follow-up period/months in group A was with a mean \pm SD of $6.25 \pm 0.26$ months, and in group $\mathrm{B}$, it was with a mean \pm SD of $6.25 \pm 0.26$ months, and there was no statistical significant difference between two groups as regard follow-up period.

Conclusion: There was no doubt that limbal auto graft was a better technique in lowering the primary pterygium recurrence than single dose intra operative bevacizumab injection with no significant difference in intra and postoperative complications.

Key Words: Pterygium - Limbal autograft transplantation Subconjunctival bevacizumab injection.

\section{Introduction}

A PTERYGIUM is a wing-shaped growth of fibro vascular conjunctiva onto the cornea. Its incidence varies across geographical locations. Several hypotheses have been ascribed to its etiology. Currently, it is believed that the pterygium is a growth disorder characterized by conjunctivalization of the cornea due to localized ultraviolet induced damage to the limbal stem cells. Aggressive pterygial fibroblasts are also responsible for corneal invasiveness [1].

Some studies have also provided evidence implicating genetic components, anti-apoptotic mechanisms, cytokines, growth factors, extracellular matrix remodeling, immunological mechanisms, and viral infections in the pathogenesis of the disease [2]

Although the pathogenesis of pterygia is still poorly understood, their formation and progression are known to depend on neovascularization. Vascular growth factors such as vascular endothelial growth factor (VEGF) have been detected in pterygium [3]. 
There is also marked elevation of VEGF in pterygia in comparison to normal conjunctival samples. It has been postulated that the development of pterygia depends on a changed angiogenic stimulator-to-inhibitor ratio [4].

The indications for surgery include reduced vision due to encroachment on the visual axis and irregular astigmatism, chronic irritation and recurrent inflammation, restriction of ocular motility, and cosmoses. Numerous surgical techniques including bare sclera excision with or without the use of adjuncts like beta irradiation, intra- or postoperative mitomycin C (MMC) or antineoplastic agents, amniotic membrane transplantation, conjunctival auto graft (CAG) have been described [5].

Despite these innovative procedures, recurrence continues to be a complication. Reported rates of recurrence range from $2 \%$ for excision with $\mathrm{CAG}$ to $89 \%$ for bare sclera excision. Differences in study methodology, patient characteristics, nature of pterygium, geographic area, definition of recurrence, duration of follow-up, and loss to followup are some of the factors responsible for widely varying rates of recurrence [6].

Pterygium represents a local limbal stem cell deficiency. Thus, inclusion of limbal epithelium in the conjunctival graft for pterygium surgery would achieve better anatomic and functional reconstruction after pterygium removal and, by restoring barrier function of the limbus, could reduce recurrence [7].

Also, many studies have shown VEGF to be increased in the pathogenesis of pterygia. There are a variety of options for the management of pterygium. The over expression of VEGF in pterygium tissue led us to develop anti-angiogenic/antiVEGF therapy which could induce regression of blood vessels and hence retard progression of pterygium. The role of angiogenesis and of VEGF in ocular pathology is established including corneal neovascularization, specifically in pterygial tissue. Evidence suggests that local bevacizumab may be effective in treatment of ocular surface neovascularization [8]

The aim of the present study was to compare the recurrence rate of limbal auto graft transplantation versus single intraoperative subconjunctivalBevacizumab injection after surgical removal of the primary pterygium.

\section{Patients and Methods}

This was a prospective cohort study, the study was conducted on 20 eyes (10 Patients) with primary pterygium patients, attended the outpatient clinic of the Ophthalmology Department at AlAzhar University Hospital (Cairo), during period from January 2021 to July 2021.

Patients were being divided into equal 2 groups: Group 1: Pterygiumwas be excised then limbalautograft was placed (10 eyes), and Group 2: Pterygiumwas be excised followed by subconjunctival injection of bevacizumab (10 eyes).

Each patient was informed of the risks and benefits of the procedure and provided written consent.

\section{Inclusion criteria:}

Patients of any gender and of any age group with primary pterygium and according to its growth onto the cornea the pterygia were at least grade 2.

\section{Exclusion criteria:}

Recurrent pterygium, previous history of any kind of Bevacizumab injection, cicatricial conjunctival diseases, and limbalstem cell deficiency diseases.

\section{Ocular examinations:}

All patients were subjected to:

- History taking.

- Assessment of vision and best corrected vision.

- Autorefractometer.

- IOP measurement.

- Slit lamp examination for any other pathology.

- Fundus examination.

\section{Surgical technique:}

- Anesthesia: The eye was cleaned up with instillation of topical benoxinate hydrochloride. A periocular injection was given with the anesthetic mixture of was 50:50 mixture of 2\% lidocaine hydrochloride and carbocaine hydrochloride solution periocular injections were performed using 25-gauge, 1.6-cm disposable needle.

- Sterilization: The face was cleaned up with some surgical scrub Lid speculum was placed.

- The pterygium head was taken off the cornea by sharp dissection with number 15 Bard-Parker blades or a crescent knife.

- The corneal and limbalsurfaces was smoothed by scraping with a Bart Parker blade. 
- The area of bare sclera was measured by Castroviejo calipers after pterygium excision. The measured dimensions were used to determine the exact size of the graft.

- The donor graft at the superior limbus was excised with dimensions $1.0 \mathrm{~mm}$ larger than the recipient bed.

- The dissected graft was flipped over the cornea and excision was made from limbal attachment. The free graft was carefully transferred to maintain polarity of tissue and was secured with interrupted 8.0 polyglactin sutures.

The same technique was done in group 2, followed by subconjunctival injection of bevacizumab (Avastin) $2.5 \mathrm{mg} / 0.1 \mathrm{~mL}$ in the predetermined site ( $2 \mathrm{~mm}$ superior and nasal to the crossing of fibrovascular tissue of pterygium at the limbus).

\section{Postoperative evaluation and follow-up:}

Patients were evaluated by photo slit lamp and slit lamp examination on the 1 st post-operative day, one week, one month, after 3 months and after 6 monthes. Visual acuity, refraction, and IOP were measured in each visit. Evaluation is for the occurrence of any complication or recurrence.

\section{Statistical analysis:}

Data were fed to the computer and analyzed using IBM SPSS Corp. Released 2013. IBM SPSS Statistics for Windows, Version 22.0. Armonk, NY: IBM Corp. Qualitative data were described using number and percent. Quantitative data were described using mean, standard deviation for parametric data after testing normality using ShapiroWilk test. Significance of the obtained results was judged at the $(0.05)$ level. $p$-value $<0.05$ was considered significant.

Qualitative data: Chi-Square test for comparison of 2 or more groups. Fischer Exact test was used as correction for Chi-Square test when more than $25 \%$ of cells have count less than 5 in $2 * 2$ tables. Parametric tests: Student $t$-test was used to compare 2 independent groups.

\section{Results}

This was a prospective study that included 20 eyes, 10 eyes of male patients and 10 eyes of female patients with age ranged from (40-57 years). Size of pterygim in $(\mathrm{mm})$ in studied groups ranged from $(3.56 \pm 0.39)$ in group 1 , and ranged from $(3.42 \pm 0.23)$ in group 2 . The postoperative recurrence rate difference between group 1 (no recurrence) and group 2 (2 recurrent pterygium) (Table 1).
Table (1): Demographic characteristics, preoperative pterygium Size/mm and recurrence distribution of the studied groups.

\begin{tabular}{llll}
\hline & $\begin{array}{c}\text { Group 1 } \\
\mathrm{n}=10\end{array}$ & $\begin{array}{c}\text { Group 2 } \\
\mathrm{n}=10\end{array}$ & $\begin{array}{c}p \text { - } \\
\text { value }\end{array}$ \\
\hline $\begin{array}{l}\text { Age/years: } \\
\text { Mean } \pm \mathrm{SD}\end{array}$ & $47.0 \pm 7.41$ & $51.0 \pm 6.65$ & 0.220 \\
$\begin{array}{l}\text { Sexn (\%): } \\
\text { Male }\end{array}$ & $5(50.0)$ & $5(50.0)$ & 1.0 \\
$\quad$ Female & $5(50.0)$ & $5(50.0)$ & \\
Occupationn $(\%):$ & & & \\
$\quad \begin{array}{l}\text { Not working } \\
\text { Working }\end{array}$ & $3(30.0)$ & $4(40.0)$ & 1.0 \\
Size/mm: & $7(70.0)$ & $6(60.0)$ & \\
$\quad$ Mean \pm SD & $3.56 \pm 0.39$ & $3.42 \pm 0.23$ & 0.220 \\
Recurrence n $(\%):$ & & & \\
$\quad \begin{array}{l}\text { No recurrence } \\
\text { Recurrence }\end{array}$ & $10(100.0)$ & $8(80.0)$ & 0.474 \\
\hline
\end{tabular}

The postoperative improvement of VA difference between group 1 (90\% improvement) and group 2 (80\% improvement). The postoperative congestion difference between group 1 (30\% congestion) and group 2 ( $0 \%$ congestion). The postoperative ischemia difference between group 1 ( $0 \%$ ischemia) and group 2 (40\% ischemia) (Table 2).

Table (2): Postoperative improvement of VA, congestion and ischemia in studied groups.

\begin{tabular}{|c|c|c|c|}
\hline & $\begin{array}{c}\text { Group } 1 \\
n=10\end{array}$ & $\begin{array}{c}\text { Group } 2 \\
n=10\end{array}$ & $\begin{array}{c}p- \\
\text { value }\end{array}$ \\
\hline \multicolumn{4}{|c|}{ Improvement of VA $n(\%)$} \\
\hline$-\mathrm{ve}$ & $1(10.0)$ & $2(20.0)$ & 1.0 \\
\hline +ve & $9(90.0)$ & $8(80.0)$ & \\
\hline \multicolumn{4}{|c|}{ Congestion $n(\%)$ : } \\
\hline$-\mathrm{ve}$ & $7(70.0)$ & $10(100.00$ & 0.211 \\
\hline$+\mathrm{ve}$ & $3(30.0)$ & $0(0.0)$ & \\
\hline \multicolumn{4}{|c|}{ Ischemia $n(\%)$ : } \\
\hline$-\mathrm{ve}$ & $10(100.0)$ & $6(60.0)$ & 0.087 \\
\hline +ve & $0(0.0)$ & $4(40.0)$ & \\
\hline
\end{tabular}

The postoperative lacrimation difference between group 1 ( $0 \%$ lacrimation) and group 2 (5\% lacrimation) was statistically significant. The postoperative irritation difference between group 1 (70\% irritation) and group 2 (0\% irritation) was statistically significant (Table 3). 
Table (3): Postoperative lacrimation, irritation and follow-up period/months in studied groups.

\begin{tabular}{|c|c|c|c|}
\hline & $\begin{array}{c}\text { Group } 1 \\
n=10\end{array}$ & $\begin{array}{c}\text { Group } 2 \\
n=10\end{array}$ & $\begin{array}{c}p- \\
\text { value }\end{array}$ \\
\hline \multicolumn{4}{|l|}{ Lacrimation $n(\%)$ : } \\
\hline$-\mathrm{ve}$ & $10(100.0)$ & $5(50.0)$ & 0.01 \\
\hline$+\mathrm{ve}$ & $0(0.0)$ & $5(50.0)$ & \\
\hline \multicolumn{4}{|l|}{ Irritation $n(\%)$ : } \\
\hline$-\mathrm{ve}$ & $3(30.0)$ & $10(100.0)$ & 0.003 \\
\hline$+\mathrm{ve}$ & $7(70.0)$ & $0(0.0)$ & \\
\hline \multicolumn{4}{|l|}{ Follow-up period/months: } \\
\hline Mean \pm SD & $6.25 \pm 0.26$ & $6.25 \pm 0.26$ & 1.0 \\
\hline
\end{tabular}

Size of pterygium in $(\mathrm{mm})$ in studied groups ranged from (3.56 \pm 0.39$)$ in group 1 , and ranged from $(3.42 \pm 0.23)$ in group 2 (Fig. 1).

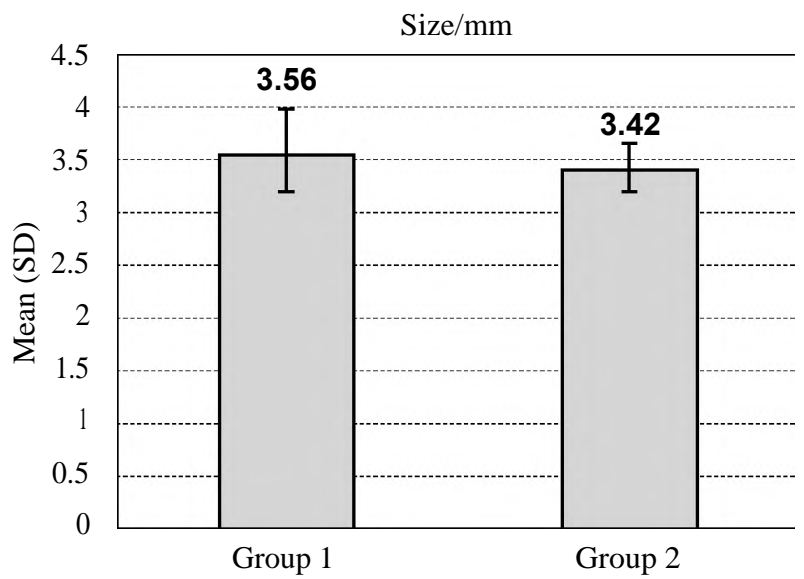

Fig. (1): Lesion size distribution among studied groups.

The postoperative recurrence rate difference between (0\%) and group 2 (20\%) (Fig. 2).

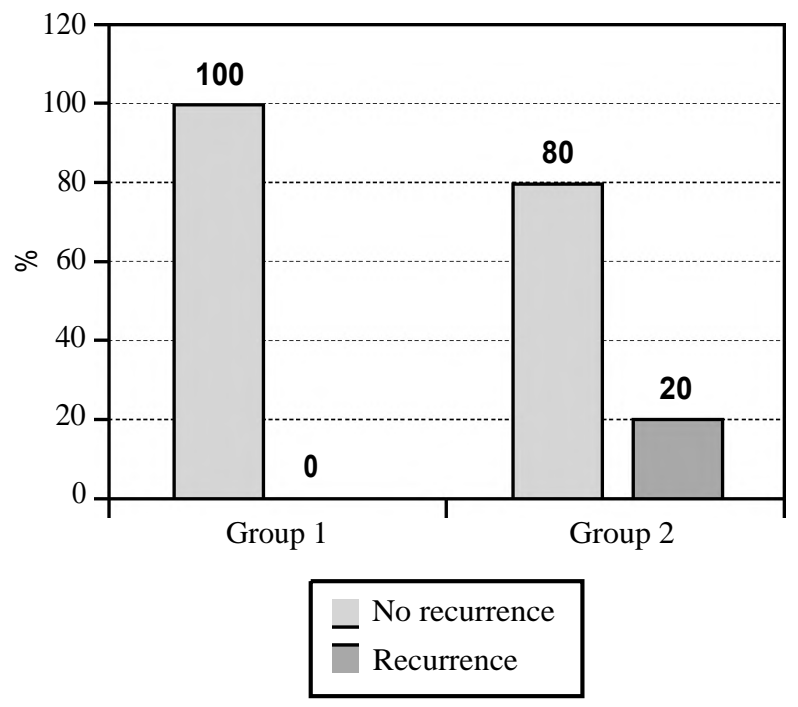

Fig. (2): Recurrence rate among studied groups.
The postoperative improvement of VA difference between group 1 (90\% improvement) and group 2 (80\% improvement). The postoperative congestion difference between group 1 (30\% congestion) and group 2 ( $0 \%$ congestion). The postoperative ischemia difference between group 1 (0\% ischemia) and group 2 (40\% ischemia). The postoperative lacrimation difference between group 1 (0\% lacrimation) and group 2 (5\% lacrimation). The postoperative Irritation difference between group 1 (70\% irritation) and group 2 (0\% irritation) (Fig. 3).

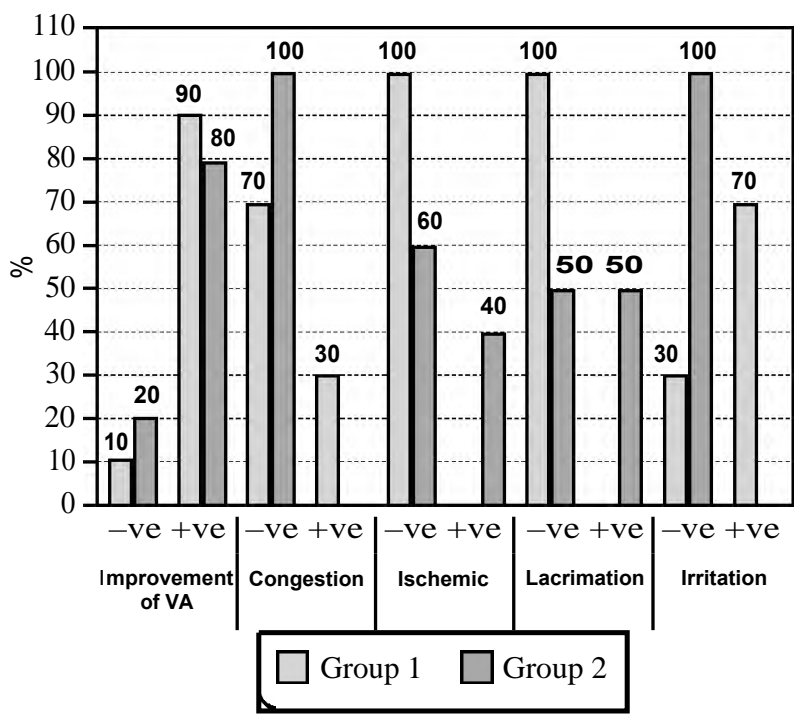

Fig. (3): Complications distribution among studied groups.

\section{Discussion}

Analysis of our findings revealed that the mean of age of the limbalautograft group was $47.0 \pm 7.41$ years old, while in subconjunctival injection of bevacizumab group was $51.0 \pm 6.65$ years old, and revealed that there were non-statistical significant differences between two groups as regard age, sex and occupation. High incidence of pterygium at this age may be due to maximum exposure to sunlight and various irritants in this age.

This finding was in agreement with Gulani and Gulani [9] who studied 21 eyes with the highest incidence of pterygia in the age group (27-79) years with a mean age $(41.8 \pm 9.33)$ years, and Jamali et al., [10] who studied 8 eyes, and found a high incidence of pterygia in the age group (34$59)$ years with a mean age $(42.6 \pm 5.38)$ years.

In agreement with the current study the study of Ozsutcu et al., [11] which was conducted on 90 patients, the mean of age of the limbalautograft group was $42.55 \pm 10.23$ years old, while in subcon- 
junctival injection of bevacizumab group was $40.8 \pm 10.23$ years old, There were no statistically significant differences between the groups regarding sex $(p=0.67)$ or age $(p=0.68)$.

In the current study, patients were followed-up for a minimum of 6 months, we found that $100 \%$ in limbal group were not recurrent, and $20 \%$ of the conjunctival injection group was recurrent, and there was non-statistical significant difference between two groups as regard recurrence.

In contrast to our findings, the study of Yousef [12] reported recurrence rate about $6.7 \%$ of group A, where $40.0 \%$ of group B showed recurrence. In comparison between two groups according to recurrence there were statistically significant difference between two groups ( $p=0.031)$.

Patel et al., [13] in study reported pterygium recurrence in $(7.4 \%)$ and 7 patients respectively after limbal stem cell autograft technique for pterygium treatment.

In another study done by El Shafie et al., [14] early pterygium recurrence was noted in five patients $(8.3 \%)$ at the 6-month visit (all of them had primary pterygia). Four recurrences occurred in the control group, at a percentage of $20 \%$ of this group. Only one case occurred in the patients of primary pterygia who received preoperative avastin at a percentage of $5 \%$ in this group.

In the study of Hussain et al., [15], it was found $12.9 \%$ recurrence out of 41 patients with limbalconjunctival stem cells autograft for primary pterygia so prevention of pterygium recurrence $(87.1 \%)$ is significant.

In study, we found that $90 \%$ in group A were $+v e$ as regard improvement in visual acuity, and $80 \%$ of the participants in the group B had +ve improvement in visual acuity, and there was nonstatistical significant difference between the groups.

In agreement with our findings, the study of El Shafie et al., [14] reported that no patient lost vision after the procedure, with visual acuity being maintained or improved in all.

Singh et al., [16], also reported in their study that postoperatively, In Group A, there was improvement of 1 line on Snellen's chart in 30\% patients of group A and improvement of two lines in $6.67 \%$. Visual acuity remained same in $63.34 \%$ patients of group A. In Group B, improvement of one line was there in $26.67 \%$, and of two lines in $6.67 \%$. Visual acuity remained same in $66.67 \%$ patients. No worsening was noted in any of the groups.

In Other Study, as regard congestion and ischemia; it was found that $70 \%$ of cases in group A had no congestion while all cases in group B had no congestion, and there was no statistical significant difference between two groups, while as regard ischemia, we found that all cases in group A had no ischemia while $40 \%$ in group B develop postoperative ischemia, and there was no statistically significant difference between two groups as regard ischemia.

Rotational conjunctival flaps to cover the pterygium excisional site have been employed since the 1940s. Ozsutcu et al., [11] reported in their study thatthere were no serious complications in these cases. The most frequent symptom after this procedure was the formation of folds over the conjunctiva as a result of rotated tissues in the flap area. Although these folds can result in unsatisfactory cosmesis, including hyperemia at the beginning, after a time the conjunctiva improves and reaches an acceptable level cosmetically. Conjunctival flap tissue that is placed over bare sclera is adjacent to the excised pterygium tissue, and altered limbal cells that might be localized on the flap could contribute to the development of recurrence, Ozsutcu et al., [11] prefer this classical technique because it is easy to apply, but it also demonstrates that surgery alone cannot prevent recurrence.

In the current study, we found that there was statistically significant difference between two groups as regard lacrimation which was -ve in all cases in group A, and irritation which was better in group B.

Teng et al., [17] found that one week post injection of a single dose of bevacizumab $(0.05 \mathrm{ml})$, the irritation and hyperemia showed near-total regression. At 2 week, the pterygium maintained this appearance. By 7 week, the degree of vascularity and symptoms of irritation had returned to its pre injection state.

Rashid et al., [18] found that sub-conjunctival bevacizumab injection was useful in management of patients with primary pterygium with local or systemic adverse effects. There was a significant difference in the mean surface area of pterygium.

Yousef et al., [12] reported no complications during and after the injection of bevacizumab. There were no intraoperative complications in both groups. By the end of the follow-up period one 
case of recurrence occurred in group A, and six case of recurrence occurred in group $\mathrm{B}$.

Singh et al., [16] study, 3 patients developed graft edema, 4 subconjunctival hemorrhage, 2 conjunctival cysts and 5 recurrences. No local irritation, allergic reaction, surface epitheliopathy, or uveitis was observed. This is in contrast with a $60 \%$ rate of spontaneous loss of epithelial integrity as recently reported by Kim et al., [19] where the investigators used topical bevacizumab at a slightly higher concentration $(1.25 \%)$ twice daily for a much longer period ( 3 months), and adverse effects generally appeared during the 2 nd month of treatment.

In the current study, the mean \pm SD size in group A was $3.56 \pm 0.3 \mathrm{~mm}$, and was $3.42 \pm 0.23 \mathrm{~mm}$ in group $\mathrm{B}$, and there was no statistically significant difference between two groups.

Singh et al., [16] reported that the mean pterygium size in Group A was $60.52 \pm 3.90 \mathrm{~mm}^{2}$ preoperatively, which decreased to $59.08 \pm 3.68 \mathrm{~mm}^{2}$ after bevacizumab injection. The mean pterygium grade in Group A was $2.43 \pm 0.09$ preoperatively, which decreased to $2.13 \pm 0.12$ after bevacizumab injection. The mean pterygium color intensity in Group A was $3.13 \pm 0.13$ preoperatively, which decreased to $2.56 \pm 0.15$ after bevacizumab injection. No change was observed in size, grade, or color intensity of pterygia for 1 week in Group B. The intergroup comparison between two groups was not significant.

In the present study, follow-up period/months in group A was with a mean \pm SD of $6.25 \pm 0.26$ months, and in group B, it was with a mean \pm SD of $6.25 \pm 0.26$ months, and there was no statistical significant difference between two groups as regard follow-up period.

In comparison to our findings, the study of Cakmak et al., [20] the mean follow-up period was $14.3 \pm 6.5$ months (6-24 months). Another study of Karalezli et al., [21], reported that the mean follow -up duration was $29.3 \pm 4.2 \mathrm{mo}(24-52 \mathrm{mo})$ and $28.5 \pm 3.4(24-48 \mathrm{mo})$ in group 1 and 2 , respectively.

\section{Conclusion:}

According to our results there was no doubt that limbal auto graft was a better technique in lowering the primary pterygium recurrence than single dose intra operative bevacizumab injection with no significant difference in intra and postoperative complications.
Though the auto graft technique is a more challenging one, but it is a better way to go in lowering recurrence especially in young patients often work outdoors.

\section{References}

1- XIE H.T., ZHANG Y.Y., JIANG D.L., WU J., WANG J.S. and ZHANG M.C.: Amniotic membrane transplantation with topical interferon alfa-2b after excision of ocular surface squamous neoplasia. Int. J. Ophthalmol., 11 (1): 160-162, 2018.

2- WYNN T.A. and RAMALINGAM T.R.: Mechanisms of fibrosis: Therapeutic translation for fibrotic disease. Nature Medicine, 18 (7): 1028-35, 2012.

3- CARDENAS-CANTU E., ZAVALA J., VALENZUELA J. and VALDEZ-GARCIA J.E.: Molecular basis of pterygium development. In Seminars in Ophthalmology, 31: 567-583, 2016.

4- PENG M.L., TSAI Y.Y., TUNG J.N., CHIANG C.C., HUANG Y.C., LEE H. and CHENG Y.W.: Vascular endothelial growth factor gene polymorphism and protein expression in the pathogenesis of pterygium. British Journal of Ophthalmology, 98 (4): 556-561, 2014.

5- SATISH K., PRAKASH D.N., TANWAR M. and GOPAL M.: A comparative study of free conjunctivalautograft versus conjunctivalautograft with stem cell transfer in primary pterygium. Journal of Evolution of Medical and Dental Sciences, 2 (45): 8805-8813, 2013.

6- ALAMDARI D.H., SEDAGHAT M.R., ALIZADEH R., ZAREI-GHANAVATI S., NASERI H. and SHARIFI F. Comparison of autologous fibrin glue versus nylon sutures for securing conjunctivalautografting in pterygium surgery. International Ophthalmology, 38 (3): 1219-1224, 2018.

7- DI GIROLAMO N.: Moving epithelia: Tracking the fate of mammalian limbal epithelial stem cells. Progress in Retinal and Eye Research, 48: 203-225, 2015.

8- BOCK F., MARUYAMA K., REGENFUSS B., HOS D., STEVEN P., HEINDL L.M. and CURSIEFEN C.: Novel anti (lymph) angiogenic treatment strategies for corneal and ocular surface diseases. Progress in Retinal and Eye Research, 34: 89-124, 2013.

9- GULANI A.C. and GULANI A.A.: Cosmetic Pterygium Surgery: Techniques and Long-Term Outcomes. Clinical Ophthalmology, 14: 1681-85, 2020.

10- JAMALI H., ABUALI M. and KHALILI M.R.: Clinical Outcomes of Silk versus Nylon Sutures for Suturing of ConjunctivalAutograft in Pterygium Surgery. Middle East Afr. J. Ophthalmol., 27 (2): 110-116, 2020.

11- OZSUTCU M., AYINTAP E., AKKAN J.C., KOYTAK A. and ARAS C.: Repeated bevacizumab injections versus mitomycin $\mathrm{C}$ in rotational conjunctival flap for prevention of pterygium recurrence. Indian Journal of Ophthalmology, 62 (4): 407-411, 2014.

12- YOUSEF H.S.: Evaluation of Adjunctive Subconjunctival Injection Of Bevacizumab Before Pterygium Surgery, AlAzhar Assiut Medical Journal, 13 (2): 26-32, 2015.

13- PATEL D., VALA R., SHAH H., BRAHMBHATT J.N., KOTHARI R.N. and SHEEDHAR V.: Efficacy of limbalconjunctivalautograft surgery with stem cells in primary 
and recurrent pterygium. Gujarat Medical Journal, 70: 17-20, 2015.

14- EL SHAFIE A.M., MOHAMED A.S. and SAYED M.F.: The outcome of preoperative subconjunctivalbevacizumab injection in pterygium surgery. Journal of the Egyptian Ophthalmological Society, 107 (2): 113-117, 2014.

15- HUSSAIN Z., REHMAN H.U. and BILAL M.: Comparison of preoperative injection vs intraoperative application of mitomycin c in recurrent pterygium. Ophthalmology Update, 11: 21-24, 2013.

16- SINGH P., SARKAR L., SETHI H.S. and GUPTA V.S.: A randomized controlled prospective study to assess the role of subconjunctivalbevacizumab in primary pterygium surgery in Indian patients. Indian Journal of Ophthalmology, 63 (10): 779-784, 2015.

17- TENG C., PATEL N. and JOCOBSON L.: Effect of
subconjunctivalBevacizumab on pterygium: Case Report. Cornea, 28: 468-470, 2011.

18- RASHID O., SAROSH R., WASEEM R. and RASHID A.: Role of Subconjuctival Bevacizumab in treatment of pterygium. Pak. J. Opthalmol., 28: 132-135, 2012.

19- KIM S.W., HA B.J., KIM E.K., TCHAH H. and KIM T.I.: The effect of topical bevacizumab on corneal neovascularization. Ophthalmology, 115: 33-38, 2011.

20- CAKMAK H.B., DERELI C.G., CAN M.E. and CAGIL N.: A novel graft option after pterygium excision: Plateletrich fibrin for conjunctivoplasty. Eye, 31 (11): 1606-1612, 2017.

21- KARALEZLI A., KUCUKERDONMEZ C., AKOVA Y.A. and KOKTEKIR B.E.: Does topical bevacizumab prevent postoperative recurrence after pterygium surgery with conjunctivalautografting? Int. J. Ophthalmol., 7 (3): 512 516, 2014.

\section{مقارنة بين زدع الطعم الذاتى الحوفى وحقن بيفاسيزو ماب تحت الملتحمة

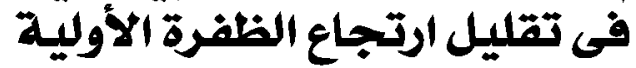

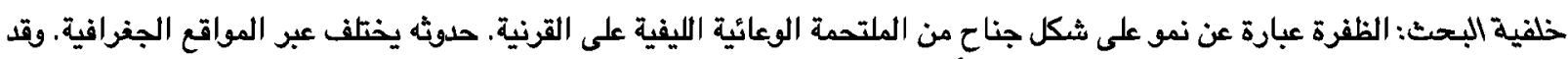

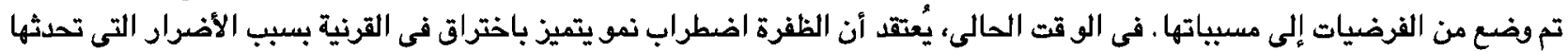

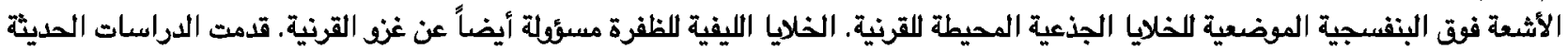

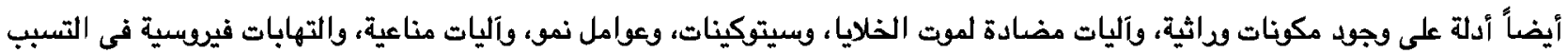
فى المرض.

الهدف من البحث: مقارنة معدل تكراد زرع الطعم الذاتى فى الحوفى مقابل حقن بيفاسيزوماب تحت الملتحمة الفردى أثثاء العملية بعد الاستئصال الجراحى اللظفرة الأولية.

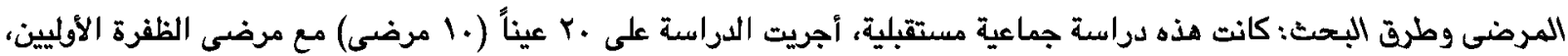

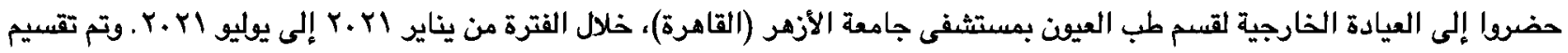

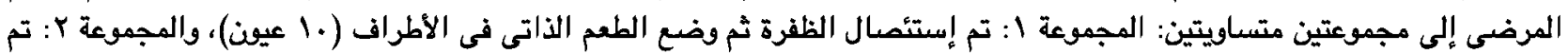

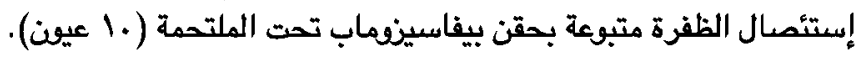

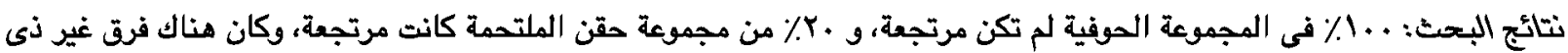

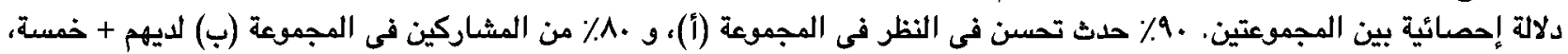

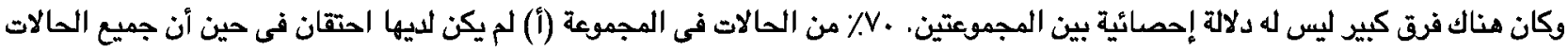

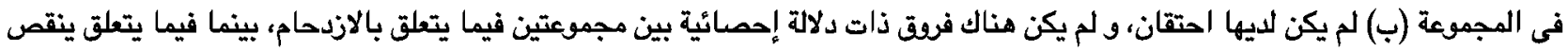

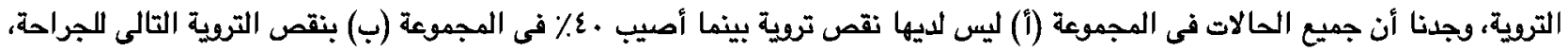

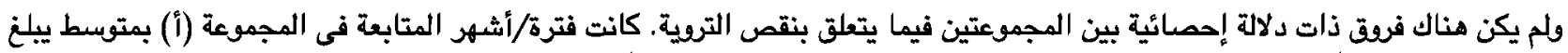

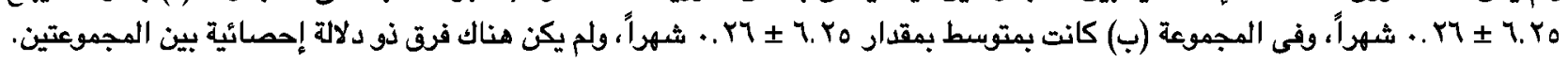

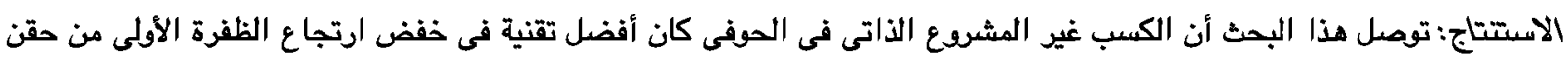

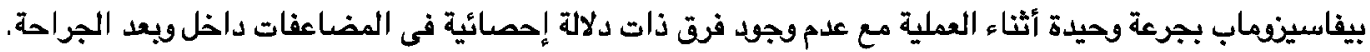

